\title{
Leadership Turnover and Foreign Policy Change: Societal Interests, Domestic Institutions, and Voting in the United Nations*
}

\author{
MichaELA MATTES \\ University of California, Berkeley \\ BRETT ASHLEY LEEDS \\ Rice University \\ AND \\ ROYCE CARROLL \\ Rice University
}

forthcoming, International Studies Quarterly

\begin{abstract}
* Author's note : Earlier versions of this paper were presented at the "The International Politics of Autocracies” workshop at Rice University, May 3-5, 2012, the annual meeting of the Peace Science Society, Savannah, GA, October 26-27, 2012, the annual meeting of the American Political Science Association, Washington, DC, September 2-5, 2010, and at seminars at the University of Virginia, the University of California-Berkeley, and Binghamton University. The research was supported by NSF grant SES-0921830. All authors contributed to the manuscript equally. The authors thank Josh Clinton, Courtenay Conrad, Cliff Morgan, Jim Morrow, Todd Sechser, Alexander Thompson, Erik Voeten, Jessica Weeks, and other seminar and workshop participants for comments on earlier versions of this research and Anna Carella, Daina Chiba, Jaewook Chung, Matthew DiLorenzo, Jinhyeok Jang, Jesse Johnson, Naoko Matsumura, Mariana Rodriguez, and Eelco Van der Maat for research assistance. Upon publication, all data and analysis mentioned in the text and footnotes will be available at http://www.ruf.rice.edu/ leeds/.
\end{abstract}




\title{
Leadership Turnover and Foreign Policy Change: Societal Interests, Domestic Institutions, and Voting in the United Nations
}

\begin{abstract}
This study examines the effect of domestic political change on UN General Assembly voting. We argue that foreign policy change is most likely when a new leader comes to power who relies on different societal groups for support than her predecessor. We then examine whether the extent to which foreign policy behavior changes with domestic interests depends on the domestic institutional context, specifically whether a country is a democracy or not. We test our hypotheses using a new measure of UNGA voting patterns and new data on changes in leaders' supporting coalitions. We find that change in the societal support base of leaders leads to change in UN voting, especially in nondemocracies. This study lends credence to the perspective that foreign policy, like domestic policy, can vary with the particular interests that leaders represent.
\end{abstract}


What causes change in foreign policy positions? In part, foreign policy is driven by the exigencies and opportunities presented to a state as a function of its power and geographic position and the structure of the international system. However, foreign policy is also influenced by state preferences, which in turn are determined through domestic political processes. Thus, while change in foreign policy is influenced by changes in the international system and a state's position within it, domestic politics could also play an important role. Domestic political factors shaping a state's foreign policy include not only changes in the institutions that structure politics, but also changes in which societal groups hold power within those institutions.

The purpose of this study is to examine the effect of changes in domestic sources of leader support on foreign policy. Because leaders wish to stay in power, and because every leader relies on the support of some group of domestic actors to maintain her leadership position, leaders tend to pursue policies favored by their core societal support groups. While foreign policy may not be the most important factor dividing groups within society, we argue that often domestic cleavages do correspond to different foreign policy preferences. Thus, when a leader comes to power who depends on a different constellation of societal groups for support than her predecessor, policy change, including foreign policy change, becomes more likely. The level of change in foreign policy associated with changes in the domestic source of leader support may be mediated, however, by domestic political institutions. Since democratic leaders require the support of larger proportions of the population to stay in power and are more constrained by other actors, democracies should exhibit more stability in foreign policy than nondemocracies.

To test our argument about broad changes in the foreign policy positions of a state, we make use of voting patterns in the United Nations General Assembly (UNGA). The UNGA considers a wide variety of issues, which together reveal many aspects of a state's international 
alignments and foreign policy orientation (Voeten 2000, 2004). We take advantage of new data that allows us to capture over time changes in a country’s aggregate UNGA voting behavior and interpret positions on a consistent scale (Bailey, Strezhnev, and Voeten 2013; Strezhnev and Voeten 2013). We have developed rules for distinguishing leadership changes that maintain the same domestic source of leader support from those in which the leader's support base changes. Using these new data, we are able to examine whether changes in voting patterns correspond to periods in which a new leader has a different source of societal support from that of a previous leader.

Predicting changes in foreign policy positions is important to policymakers, and it is also an area in which scholars have not been systematically successful. Our results show not only that foreign policymaking is shaped by the same factors as domestic policymaking, but that the competition among domestic groups is a powerful predictor of changes in foreign policy positions, even compared to a factor traditional international relations scholars would emphasize - the shift in the structure of the international system at the end of the Cold War. We also find that changes in source of leader support result in greater foreign policy redirection in nondemocracies than in democracies.

\section{The Domestic Basis of Foreign Policy}

For much of the history of IR scholarship, analysts have implicitly or explicitly assumed that foreign policy is developed differently than domestic policy. The analysis of domestic policy focuses on the outcome of competition among groups acting through particular political institutions, while foreign policy is often assumed to be driven by international imperatives or a commonly accepted view of "the national interest.” Scholars recognize that domestic 
competition may influence "low politics" areas such as trade policy, but typically consider other areas of foreign policy to be outside the realm of political competition and not subject to partisan, sectoral, ethnic, or regional interests. ${ }^{1}$ In fact, theories of most areas of foreign policy have traditionally turned to domestic politics only as an ad hoc explanation for behavior that appears unusual from the standpoint of international variables—-for example, the isolationist turn of the United States between the two world wars. As Narizny (2007:3) writes, "The extant literature .... views domestic politics as a constraint on the pursuit of the 'national interest,' not as the fundamental determinant of state behavior.”

Increasingly, scholars have challenged this view. Snyder (1991) argues that overly expansionist grand strategies have their roots in the economic interests of narrow sectors and the ability of these sectors to logroll. Narizny $(2003,2007)$ posits that class and sectoral interests influence alliance policy and grand strategy. Solingen (2007) contends that even nuclear weapons policies are influenced by the economic interests and ideologies of leaders and their ruling coalitions. Fordham (1998) shows that the economic make-up of districts helps to explain foreign policy voting in the US Senate in the crucial early Cold War period when US grand strategy was being defined. Importantly, all of these authors suggest that different economic interests may exist within a state simultaneously and compete with one another for control of policy. The result is that changes in the coalitions that have power domestically can result in changes in foreign policy even in the area of "high politics."

Economic interests are not the only source of different foreign policy preferences within states. Regional, religious, ethnic, and ideological divisions may also affect a state's general foreign policy orientation. Davis and Moore (1997), for example, find evidence that when an

\footnotetext{
${ }^{1}$ For a review of the literature linking domestic politics to trade policy, see Milner (1999).
} 
ethnic minority has political influence in a state, that state is more likely to engage in international conflict with states repressing members of the same ethnic group. Haas (2005) and Rathbun (2004) argue that the ideological beliefs of leaders and their supporting coalitions influence international alignments and support for peace enforcement missions. Finally, Trubowitz (1998) interprets major disputes over American grand strategy as conflicts among regional interests—North vs. South and East vs. West—-that emerge as a result of uneven regional economic development.

While certainly IR scholars have embraced the importance of domestic influences on foreign policy, much of the large $\mathrm{N}$ research on this subject has emphasized the influence of domestic political institutions. These institutions, which define the decision-making process and accountability structure for a regime, change little across time and best provide cross-sectional explanations for variation in foreign policy. By contrast, the policies pursued by leaders through these institutions reflect shorter-term change in the groups to whom they are accountable. We believe changes in which domestic interests support the leader can provide considerable additional leverage in understanding changes in a state's alignments and foreign policy positions.

Consider, for instance, the following examples. In Ukraine, a major source of political competition is between ethnic Russians based primarily in the East and ethnic Ukrainians based largely in the West. While under President Yushchenko Ukraine actively pursued NATO membership, the election of Yanukovych in 2010 was followed nearly immediately by a halting of that process. There are no obvious institutional or international changes that can account for this sudden shift in alignment strategy (Shoemaker 2013:176). Similarly, in 2005, President Akayev of Kyrgyzstan, who was associated with a clan from the North, resigned after protests. His successor was Bakiyev, who was associated with a southern clan. The South is not only 
poorer, but also includes many ethnic Uzbeks and a more conservative Muslim population than is found in the North (Olcott 2005:108). Bakiyev pursued a "more independent foreign policy" that was perceived as more confrontational to the US (Cooley 2012:233).

In this paper, we build on the idea that despite the constraints and imperatives of the international system, leaders retain meaningful choices in the foreign policies they pursue. As we elaborate below, we believe that these choices are influenced by the interests and preferences of societal groups that the leader represents and the domestic institutional context.

\section{Domestic Interests, Institutions, and Foreign Policy Change}

In 1997, Moravscik published an influential outline of liberal IR theory, which, in his view, gives primacy of place to the interests of domestic groups and their differing abilities to influence state leaders (Moravscik 1997). We build our theory on assumptions similar to Moravscik's. We assume that, within societies, there are more or less well defined groups of like-minded individuals who share political interests as a result of their economic, ethnic, religious, regional, or other characteristics and thus have similar policy preferences on at least some issues. These groups compete with one another for political influence. We further assume that leaders wish to stay in power and that maintaining power requires retaining the support of some subset of these societal groups. The number of supporters necessary to stay in power depends on the country's political institutions. Yet, the number of necessary supporters is smaller than the total set of people with a say in choosing leaders. (In Bueno de Mesquita, Smith, Siverson, and Morrow's (2003) terms, the winning coalition is smaller than the selectorate.) Thus, a leader may be replaced by a successor who depends on the support of a different subset of the population for the retention of power even without significant institutional change. 
Given that different domestic groups may have divergent preferences regarding international issues, we expect that foreign policy changes are most likely when a leader who depends on the support of a different societal group, and thus caters to different interests and preferences than her predecessor, comes to power. On the other hand, when a leader relies on the same source of support as her predecessor, we should see less change in policy.

Consider, for instance, the 2005 transition from Khatami to Ahmadinejad in Iran. While Supreme Leader Khamenei possesses ultimate authority over Iran’s foreign policy and there were no obvious institutional changes accompanying this transition, the Khatami government took a more conciliatory approach to the West and embraced aspects of globalization, while Ahmadinejad was a staunch anti-Americanist, famous for his tirades in the UNGA. Khatami relied on the support of "technocrats, younger entrepreneurs, and bazaar (bazaari) merchants and traders pressing for decreased state control, [seeking] privatization, increased trade with Europe and Asia, a utilitarian over an ideological approach to foreign policy, and decreased tensions with international institutions" as well as women and youth who did not share the same revolutionary fervor as their parents (Solingen 2007:178). Ahmadinejad, on the other hand, had the support of the Revolutionary Guards, paramilitary youth groups, and social conservatives among the clergy and bazaari. Ahmadinejad opted for inward-looking economic policies that benefitted his supporters. Even Iran's nuclear policy can be seen as advancing his supporters' interests since sanctions shelter their businesses from competition and allow them to benefit from selling banned products (Solingen 2007:180-181).

Leaders with different sources of societal support sometimes prefer to pursue different foreign policies. Yet, whether a change in the domestic source of leader support actually results in noticeable change in foreign policy positions might also depend on the domestic institutional 
context. There are two important sets of political institutions within states that influence the extent to which new leaders representing different core societal interests are likely to redirect foreign policy: those affecting the rules of leader selection and those affecting the rules of policymaking.

According to Bueno de Mesquita et al.’s (2003) selectorate theory, rules of leader selection that require leaders to gain the support of large numbers of citizens (as we expect in democracies) encourage leaders to pursue policies that provide public goods. The incentive to produce broader public goods should create consistency in the types of policies pursued by different democratic leaders. In addition, when winning coalitions are large, it is likely that some members of one leader's winning coalition also are incorporated in her successor's winning coalition. While a leader might represent primarily interests on the right of the political spectrum and her successor might represent those on the left, both leaders should seek to include some centrist elements (that is, the median voter) in their coalitions. Thus, the need to provide public goods to one's winning coalition and the incentive to appeal to the median voter should induce some level of consistency in the policies of democratic leaders.

On the other hand, leaders operating in systems in which only a small number of supporters is necessary to stay in power benefit most from providing private goods to their “winning coalition.” When a new leader in a small winning coalition state (as in many nondemocracies) comes to power, there may be little overlap in coalition members and the particularistic policies preferred by her small coalition compared to her predecessor's. Compared to democracies, we should see greater change on average between the policies of leaders with different support coalitions when those leaders depend on the support of only a few to stay in office (McGillivray and Smith 2008). 
The rules of leadership selection thus influence the extent to which leaders are likely to pursue broad-based public policies as opposed to the provision of narrowly-based private goods, and the probability that there is overlap between one ruler's supporting coalition and that of her successor. Rules governing the policymaking process also have an influence on the ease with which a new leader can implement the policies she prefers. Some chief executives are relatively unconstrained in their ability to make and change policy. On the other hand, many chief executives operate in systems in which the consent of other political actors is necessary for the formulation of policy. The latter is more often associated with democracies. Legislatures, for example, often have influence over the appropriation of funds, personnel appointments, the implementation of executive directives, and treaty ratification, which are important for the pursuit of foreign policy (Martin 2000). Similarly, coalition partners and subnational leaders often have a say in policymaking and a role in mobilizing resources for policy implementation. The need to cooperate with other actors, some of whom may represent interests outside the chief executive's own winning coalition, might limit the extent to which a new leader can pursue a foreign policy that is notably different from her predecessor's.

Democracies generally combine features of leadership selection rules and policymaking rules that should discourage dramatic change in policy. Thus, given a change in the core societal supporting coalition of a leader, foreign policy positions should be subject to less subsequent change in democratic systems than in nondemocratic ones. This is in line with previous arguments about democratic stability, many of which were developed and tested with formal international agreements in mind (for example, Gaubatz 1996; Martin 2000; Lipson, 2003; Leeds, Mattes, and Vogel 2009). While democracies should display more consistent foreign policy patterns than nondemocracies, we believe that in all states change in foreign policy 
positions is more likely when new domestic groups gain influence over policymaking than it is when leaders depend on similar domestic groups to retain power.

\section{Domestic Political Change and Voting in the UN General Assembly}

An arena in which we may be able to witness and measure changes in the general foreign policy orientation of states is voting in the United Nations General Assembly (UNGA). The UNGA is the only forum in which all countries have the opportunity to express their views on issues that confront the international community. While wealthy and powerful countries are able to communicate their foreign policy positions in a number of ways (through foreign aid, economic sanctions, or the use of force, for instance), the foreign policy tools of developing states tend to be more limited. For them, the UNGA annual meetings provide a particularly valuable opportunity for making their views heard (Vengroff 1976; Moon 1985).

The UNGA covers a wide range of international issues such as the North-South gap, disarmament, and human rights. Occasionally topics covered in the UNGA are directly relevant to domestic constituencies, and different societal groups take different stances on these issues (Moon 1985). Many issues considered by the UNGA, however, do not map directly to domestic

cleavages. On these issues, large portions of the domestic population are likely indifferent to the specific topics under consideration in the UNGA. Thus, we do not see UNGA voting as directly reflecting the interests of domestic groups with regard to particular votes. Instead, we view UNGA voting patterns as providing an indirect reflection of the foreign policy position of a state that corresponds to the broad preferences of domestic groups for alignment with or distance from particular states. Many UNGA resolutions, for example, represent declarations of affinity or disagreement with other states, and governments' votes on these topics reflect their 
constituencies' preferences of who to ally with and who to oppose on the international stage. In the aggregate, a country's voting record in the UNGA is a latent indicator of its foreign policy orientation and international alignments; it is a record of how the state wants to be seen by others, the international norms it finds acceptable, and the positions it is willing to take publicly on a wide variety of issues.

UNGA voting is particularly informative regarding domestically motivated changes in a country's foreign policy positions for three reasons. First, unlike treaty cooperation, UN voting is not regulated by international law and countries are free to revise their positions as frequently and as much as they desire. Second, the non-binding nature of most UNGA resolutions makes it more likely that a country’s overall behavior can reflect a reaction to the views of important domestic constituencies rather than international strategic considerations (Gartzke 1998; Voeten 2001). While some scholars have argued that UNGA votes may be "bought," the conditions under which aid or loans influence UNGA voting appear to be limited, and evidence concerning the conditions under which this phenomenon occurs is mixed (for example, Wang 1999; Lai and Morey 2006; Dreher, Nunnenkamp, and Thiele 2008; Carter and Stone forthcoming; Dreher and Sturm 2012). Moreover, the willingness to sell one’s vote is also an indication of foreign policy, and thus even if such transfers occur, they would not undermine our claim that the aggregation of UNGA votes serves as a representation to the world of a state's chosen policy positions. Third, unlike many other foreign policy behaviors, UN voting does not strictly involve interdependence among states. For trade to occur, an alliance to form, or a war to start, at least two states must choose to participate. UNGA voting, on the other hand, may involve consultations with other countries but ultimately reflects autonomous decisions by each government. Thus UN voting patterns can more easily change as the result of domestic political shifts in a state. 
The universal membership of the UNGA, the opportunity it provides to all states to express their positions on different international issues, the lack of international legal constraints, and the fact that voting is a monadic activity make the UNGA an excellent forum for studying countries' foreign policy positions. In fact, the extent to which two countries vote together on UNGA resolutions forms the basis for a commonly used measure of interest similarity and international alignment (Gartkze 1998).

We are not the first to consider the influence of domestic political changes on UN voting. Early studies by Vengroff (1976) and Moon (1985) focus on the effect of domestic instability, especially violent leader transitions, on UN voting and report mixed findings. Hagan (1989) expands the scope of domestic changes to include non-violent changes in leadership that bring to power different groups from the same or opposite end of the political spectrum and shows that both revolutionary and non-revolutionary changes influence Third World countries’ alignment with the US between 1946 and 1984. Voeten (2001) moves beyond Hagan’s study by expanding the empirical domain to all countries, but at the same time returns to a more limited focus on how institutional shifts affect foreign policy. Finding little support for his hypotheses, he concludes that "the current dominant focus in the IR literature on the effects of domestic institutions is too restricted. The interaction between institutional arrangements and societal preferences produces political outcomes” (2001:31).

Recent studies have picked up on the notion that societal preferences and the resulting policy orientation of governments should affect a country's UN voting record. Potrafke (2009) shows that OECD countries are less likely to vote similarly to the US when their leaders are from left-leaning parties, and that this relationship is particularly strong when the US President is a Republican. Dreher and Jensen (2013) demonstrate that when a state's leader is of similar 
political orientation (that is, left or right) as the US President, the country is more likely to vote similarly to the US.

While Hagan (1989), Potrafke (2009), and Dreher and Jensen (2013) direct attention to the importance of domestic preferences and government policy orientation, they do not consider the constraining effect of different domestic political structures. Yet, like Voeten, we believe that state policy derives from the interaction between domestic interests and institutions. Our study thus sets out to connect these two components of the domestic political process and to examine their effect on voting in the UNGA, using a larger sample than previous studies as well as a new measure of changes in domestic preferences. We also make use of a measure of UNGA voting that does not depend on a comparison between the voting records of two states and thus allows us to disentangle which side is changing policy when two states move apart; this is crucial for evaluating our hypotheses about the influence of domestic political change on an individual country's behavior. In addition, this measure accounts for the problem of different issues being considered by the UNGA from one session to the next (Voeten 2013).

One thing to keep in mind when assessing the interaction of domestic political preferences with institutions is that, in UNGA voting, the influence of executive constraints should be somewhat muted in comparison to other policies like treaty formation or abrogation, the waging of war, or trade policy. Most UN votes do not require much consultation with other domestic actors directly. On the other hand, the appointment of UN ambassadors may be subject to legislative confirmation or compromise with coalition partners, and many UN votes do pave the way for foreign policy actions that require legislative action, for example treaty ratification or budgetary appropriations. Furthermore, leaders who have difficulty engaging in political action without the support of other actors will avoid casting domestically unpopular votes in the 
General Assembly in order to ensure domestic veto players’ support on issues where those actors do have a gate-keeping role. Since democratic leaders both operate under conditions of higher executive constraint and derive their policy preferences from the need to satisfy larger constituencies, democracies should exhibit more stability than nondemocracies in UNGA voting patterns, but the distinction may be less stark than in policy arenas in which other political actors have more direct influence on the policy process, for instance, treaty formation.

In the next sections we describe our research design and test the following hypotheses:

Hypothesis 1: Leadership changes accompanied by changes in domestic sources of leader support are associated with more change in the state's UNGA voting pattern than either years without leadership changes or leadership changes that are not accompanied by changes in domestic sources of leader support.

Hypothesis 2: Democratic states show more consistency in UNGA voting patterns than nondemocratic states.

Hypothesis 3: The impact of changes in domestic sources of leader support on changes in UNGA voting patterns is stronger in nondemocracies than in democracies.

\section{Research Design}

In order to test our hypotheses we take advantage of countries' yearly voting records in the UNGA between 1946 and 2008. Using the country-year as the unit of analysis allows us to contrast years in which a new leader with a different source of societal support comes to power, years in which there is a leader change but the new leader represents the same segment of society as her predecessor, and years in which there is no leadership transition. We expect that, on average, UNGA voting change is most likely to be observed in years in which a new leader with 
a different supporting coalition assumes office. ${ }^{2}$ We identify the leaders in office each year using the Archigos data (Goemans, Gleditsch, and Chiozza 2009). ${ }^{3}$ Since voting in the UNGA typically occurs late in the year, ${ }^{4}$ the country's voting record in leader transition years is attributed to the new leader rather than her predecessor. The exceptions are leader transitions that occur in the month of December. In the case of December leader transitions we attribute the country's voting record in that year to the leader in power before December 1st. If there are multiple leader transitions in a given year, we code the leader in power during November as the leader in charge of the country's voting in that year. ${ }^{5}$

Because we are interested in the change in the state's ideal point from the previous year, data from the first UNGA session for each state during our observation period is not included in the analysis. We also drop state-years in which the country did not vote in the UNGA. Finally,

${ }^{2}$ The full extent of a country's foreign policy change may not be observed immediately after a new leader takes office. Despite this limitation, we expect a new leader's first year to be associated with enough UNGA vote change to mark any distinct departure from her predecessor's policies.

${ }^{3}$ Archigos covers all independent countries from 1875-2004. Leadership transitions from 20052008 are coded based on worldstatesmen.org.

${ }^{4}$ During the 1946-2008 period, December is the month with the highest number of votes (74.7\%), followed by November (15.2\%), and then October (3.5\%). The remaining 6.6\% of votes occur between January and September (Strezhnev and Voeten 2013).

${ }^{5}$ To ensure that these coding decisions do not unduly affect the results we conducted a robustness check excluding years in which leaders took office in December as well as the subsequent year. We find that the results described below hold. 
we exclude years with interim leaders who do not represent any particular societal groups but rather are tasked with maintaining the status quo until a new regular leader takes office. ${ }^{6}$ This leaves us with 7,049 state-years from 165 countries.

Since we are interested in the determinants of change in UNGA voting for each year within each state, we employ state-level fixed effects in all models used below. This approach allows us to fully account for any unmeasured factors associated with particular countries and to isolate the effect of our independent variables on the variation within each state group. Thus we are not examining cross-sectional variation, but rather each state's degree of UNGA voting change in different years.

\section{Measuring Changes in Foreign Policy Positions Using UNGA Voting}

Our interest is in measuring changes in foreign policy positions that may arise from changes in political leadership. While individual UNGA votes do not necessarily capture specific foreign policy action, we argue that the pattern of voting captures latent tendencies in a nation's foreign policy orientation and international alignments. Behind the disparate topics on which votes occur is an underlying dimension of international cooperation and conflict that reflects the broader foreign policy positions of states, large and small.

Our measure of foreign policy change based on countries’ UNGA voting patterns must therefore be capable of capturing a latent foreign policy tendency driving a large number of individual choices across a range of topics. It must also fulfill three additional requirements. First, our measure must capture short-term changes in foreign policy that could potentially vary

\footnotetext{
${ }^{6}$ Including years with interim leaders (and coding them as cases of leader transition in which the leader's domestic source of support stays the same) produces substantively similar results.
} 
across any changes in leadership. Second, it must establish continuity across periods such that the choices made in the UNGA are comparable from session to session, rather than subject to the varying agenda of that body. Finally, our measure should detect change in each country without relying on relative similarity to any one country. By tracking a country's behavior only relative to the United States, for instance, we lose the ability to account for changes in the United States itself. $^{7}$

Recently, Bailey, et al. (2013) developed a measure that addresses each of these issues. ${ }^{8}$ They estimate the ideal points of states across time using a spatial voting model adapted to the UN setting. Using an approach similar to that of Bailey (2007), votes that occur in multiple sessions serve as "bridge votes" to anchor the preference space shared by actors across different time periods. This ensures that choices in different periods can be compared, despite changes in the UN agenda from session to session (Voeten 2013). The result of this process is an estimate of the ideal point for each country in each session that is comparable to the country's estimates in other sessions — that is, on the same scale—yet sensitive to any changes in each state's pattern of voting relative to other states on the scale. From these ideal point data, we generate a continuous

\footnotetext{
${ }^{7}$ Many scholars investigating change in UN voting have employed the affinity score (Gartzke 1998) to assess how alignment with the US changes over time. A problem with this measure for our purposes is that it does not take into account movement in the US position itself. As Voeten (2004) and Bailey et al. (2013) note, the US’s UNGA voting behavior has changed over time, and thus changes in similarity between the voting records of other states and the US might not reflect changes in the votes of other states at all. Despite this limitation, we conducted an alternate analysis using the affinity measure and found that the results described below hold. ${ }^{8}$ These data are included as part of the Strezhnev and Voeten (2013) dataset.
} 
measure of yearly changes in foreign policy positions, using the absolute value of the difference between the nation's ideal point in one year relative to the previous year.

\section{Measuring Changes in Domestic Sources of Leader Support and Regime Type}

In order to assess the effect of changes in domestic interests on UNGA voting, we need to identify instances in which a leader comes to power who has a different source of leader support (SOLS) than her predecessor. ${ }^{9}$ In our coding of SOLS changes, we rely solely on accounts of the domestic base of support of leaders and code SOLS changes independently of policy outcomes. ${ }^{10}$ To the extent possible, we also separate changes in domestic sources of leader support from changes in domestic political institutions.

Our coding rules for SOLS changes differ depending on a country's regime type. We code country-years as democratic if they have a POLITY IV democracy score of six or higher

\footnotetext{
${ }^{9}$ To identify these cases, we build on the coding rules developed by Leeds et al. (2009). We extend their data by including all countries with a population larger than 500,000. Teams of coders at two different universities coded each case. Inter-coder reliability was high, with agreement in 93.4\% of state-years with leadership transitions during 1945-2008.

${ }^{10}$ Note that our coding is designed only to measure when a leader is replaced with a leader from a distinct SOLS, as needed to test the hypotheses above. Given the wide range of domestic political environments represented in our broad sample of states, it is not possible to capture the specific foreign policy preferences of each SOLS and thus to predict a direction of change.
} 
and nondemocratic otherwise (Marshall, Jaggers, and Gurr 2010). ${ }^{11}$ In democracies, we conceptualize a leader's SOLS as those who vote for or associate with the leader's party. We follow the basic rule that whenever a leader with a different party affiliation comes to power, this constitutes a SOLS change. In cases in which a leader is an independent we follow two rules: (i) if the new leader is the pre-designated successor of the old leader, we code no SOLS change. Pre-designated successors are vice presidents, those appointed by the outgoing leader, or relatives (brother, son) of the old leader; (ii) if the voters who elected both leaders are similar based on their regional, ethnic, class etc. characteristics, we also code no SOLS change.

In nondemocracies, the identification of SOLS changes is more challenging. Here we rely primarily on Geddes, Wright, and Frantz's (2012) classification of post-1945 autocracies as single-party, military, personalist, monarchical systems or combinations thereof. The use of this categorization scheme is appropriate because their coding criteria "emphasize control over access to power and influence rather than formal institutional characteristics” (Geddes 1999:123). Geddes et al.'s classifications are thus based on identification of the groups that form the leader's support base and hold sway over policymaking. When these support bases change, we should be more likely to observe shifts in foreign policy. ${ }^{12}$

${ }^{11}$ Interruptions (-66) or interregna (-77) are considered to be nondemocratic years. Transition periods (-88) are coded as democratic or nondemocratic based on Cheibub, Gandhi, and Vreeland (2010).

${ }^{12}$ Some of these changes may also entail institutional change within the broader category of autocracies. In our data, about $30 \%$ of SOLS changes in the nondemocratic sample are associated with a change from one distinct Geddes et al. (2012) category (single party, personalist, military regime, or monarchy) to another, and institutional change might have accompanied some other 
Because in single-party systems consecutive leaders are accountable to the party cadre, and because party elites are likely to share basic policy preferences over time, we code no SOLS changes for the duration of a single-party regime. For instance, none of the leader transitions in Singapore during the observation period are coded as SOLS changes. Similarly, we code no SOLS changes for the duration of a single military regime. Studies suggest that military officers share an overarching commitment to advancing the military interest, and military leaders depend heavily on the support of other high-ranking military officers within their regime (Geddes 1999:126). Thus, different leaders within the same military regime, such as Algeria’s Zéroual and Bouteflika, should be expected to pursue relatively similar policies.

In personalist systems, because a leader's support group consists of a clique of family and friends that are loyal to that particular leader, changes in leadership are usually accompanied by changes in the source of leader support. Exceptions are pre-designated successors who build on the outgoing leader's supporters and should continue to pursue policies that are in the clique's interest. Thus, in personalist systems, we code SOLS changes if a new leader who is not a predesignated successor assumes office. For instance, as noted above, we coded the personalist-topersonalist leader transition in Kyrgyzstan in 2005 as a SOLS change, since the new leader, Bakiyev, was an opposition leader who was not favored by his predecessor's, Akayev's, clique. Conversely, Joseph Kabila's assumption of power in the DRC after his father Laurent Kabila was assassinated is not a SOLS change since Joseph could count on his father's supporters. In monarchies, if a ruler descends from the same dynasty as her predecessor, the source of support

SOLS changes during periods not coded by Geddes et al. as meeting the criteria for their classifications. Thus, it is not possible to disentangle all forms of institutional changes in autocracies from simultaneous changes in the source of leader support. 
is likely to stay the same and we thus code no SOLS change. An example here is the 1991 Saudi leader transition from Fahd to his half-brother Abdullah. ${ }^{13}$

Some country-years cannot be classified according to the Geddes et al. (2012) scheme, however. Most of these are country-years during which politics are in flux. Some of these cases are characterized by warlordism (where no particular leader can be said to be in control of the entire country and its policies) or foreign occupation (where no real domestic competition exists because policies are directed by outsiders). We treat cases in which no domestic actor has clear control over the foreign policy apparatus as experiencing no changes in domestic sources of support during the period of incapacity. Examples here are leader transitions in Liberia during the civil war and Lebanon during Syrian interference. For countries that have functioning governments but still display too much ambiguity to assign them to any of the Geddes et al. (2012) categories, we use a pre-designated successor rule.

Using these coding rules, we create a dummy variable, SOLS Change, that is coded 1 if a new leader with a different SOLS than her predecessor enters into office in a given year. We create an additional dummy variable, Other Leader Transition, to capture years in which a new leader comes to power who has the same societal support base as the outgoing leader. These two variables, SOLS Change and Other Leader Transition, are thus mutually exclusive. Democracy is coded 1 if the country is democratic (as described above) in both the year under observation and in the previous year. We expect year-to-year consistency only in a stable democratic regime.

${ }^{13}$ Geddes et al. (2012) also code some countries as hybrids of two or more of the above regime types. With some rare exceptions, we code no SOLS changes for the duration of a single hybridregime. We also categorize a few countries not coded by Geddes et al. according to their coding rules. We provide a list in our web appendix. 
If a regime transition occurs and the current leader presides over a democracy but her predecessor did not, we would expect more change in UN voting.

Of the 7,049 state-years from 1946-2008, 2,731 (39\%) are state-years in which the country was democratic both during the current year and the previous year. 4,169 observations (59\%) are cases of consecutive nondemocratic years. In 149 observations (2\%), the country experienced a transition from nondemocracy to democracy or vice versa. In 565 (21\%) of the democratic state-years a leader transition occurs, compared to 439 (11\%) of the nondemocratic country-years. Of democratic country-years that experience a leader transition, 346 (61\%) involve a SOLS change and 219 (39\%) do not. Of leader transitions in nondemocracies, 197 (45\%) are associated with SOLS changes and 242 (55\%) are not. Thus, both leadership transitions and SOLS changes are more common in democracies. ${ }^{14}$

\section{Control Variables}

Following the insights of Achen (2005), Clarke (2005), and Ray (2003), we limit our control variables to factors that have the potential to affect both UNGA voting and SOLS changes and that should thus be included to guard against spurious findings. First, we control for alliance ties with the US throughout the entire time period and with the USSR until its dissolution in 1991 by including dummy variables for whether the country had a defense pact with either superpower in a given year. During the Cold War, a close relationship with the US or the USSR likely constrained both the possibility for domestic political change and foreign policy change in allied states. The constraining effect of alliance ties to the US is also likely to have

\footnotetext{
${ }^{14}$ Differences between democracies and nondemocracies in terms of the frequency of leader transitions and SOLS changes are statistically significant.
} 
persisted after the end of the Cold War into the unipolar world order. These variables, US Ally and USSR Ally, are coded based on the ATOP dataset (Leeds and Mattes 2007). ${ }^{15}$ In 2,326 country-years (33\%) the country had a defense pact with the US and in 302 country-years (4\%) the country was a protégé of the USSR.

Second, we control for the short-term effect of the end of the Cold War. The fall of the Iron Curtain was a watershed event that led both to significant international realignments and to domestic political changes in a number of countries. To ensure that we do not falsely attribute changes in UNGA voting to SOLS changes, when really both were due to the massive changes in the international system, we include a control for whether the year coincides with the end of the Cold War-1989 through 1991. This dummy variable, Cold War End, is coded 1 in each of these years for a total of 392 state-years (6\%).

Finally, we control for regime transitions. Regime transitions from democracy to autocracy and vice versa constitute significant changes in a country's institutions that are likely to affect UN voting. Regime transitions also often involve changes in the source of leader support. Thus, in cases of regime transition, it is difficult to disentangle the effects of new institutions from the effects of changes in the leader's societal support base. Yet, while regime transitions are usually accompanied by SOLS changes, SOLS changes also occur quite

${ }^{15}$ As the ATOP (version 3.0) measure goes only until 2003, it is extrapolated to 2008. We treat those countries allied with the US in 2003 as continuing their alliance and those not allied as continuing not to be allied with the US. Our interpretation of results is similar if we include a single variable indicating whether the state was allied to either the US or the USSR. We have also examined a version using the COW data, version 4.1 (Gibler 2009): US ally is negative and statistically significant at the .1 level, but our main conclusions are similar. 
frequently in the absence of this kind of dramatic institutional change. ${ }^{16}$ By controlling for years representing transitions between democracy and autocracy, we provide a more conservative test that is better at isolating the pure effects of changes in sources of leader support. Regime Transition is coded 1 if there is a change in a country's POLITY IV democracy score from 6 or above to below 6 or vice versa in a given year. ${ }^{17} 149(2 \%)$ of state-years experience such a regime transition.

\section{Empirical Results}

Given the continuous nature of our dependent variable-- the absolute change in the country's UNGA ideal point from $t-1$ to $t--$ we use OLS regression. The dependent variable is logged in order to approximate a normal distribution. All models include state-level fixed effects, which account for unmeasured factors associated with particular countries. Thus, we estimate the effects of our independent variables on within-country variation in UNGA vote change. ${ }^{18}$ In addition, we also estimate robust standard errors clustered on the country in order to deal with

${ }^{16}$ We code a SOLS change in $63 \%$ of regime transitions, but only $15 \%$ of SOLS changes occurred when there was also regime transition. The correlation between SOLS change and regime transition is 0.28 .

${ }^{17}$ Given that UN voting occurs late in the year, we code regime transitions as affecting UN voting in the current year unless they occur in December, in which case they are coded as affecting voting in the following year.

${ }^{18}$ A Hausman test suggests that fixed effects are appropriate, but the results are substantively similar when employing state random effects. The results are also robust when the dependent variable is not logged. 
remaining concerns regarding the nonindependence of observations stemming from the same state.

We begin our analysis with a simple model that includes our main theoretical variables of interest: SOLS change, Other Leader Transition, and Democracy (Model 1). In a second model (Model 2), we then include the control variables: Regime Transition, Cold War End, US Ally, and USSR Ally.

TABLE 1. Change in UNGA Voting as a Function of SOLS Change, Other Leader Transitions and Regime Type, 1946-2008

\begin{tabular}{|c|c|c|c|c|}
\hline & $\begin{array}{c}(1) \\
\text { Basic Model } \\
\text { (No Controls) } \\
\end{array}$ & $\begin{array}{c}\text { (2) } \\
\text { Basic Model } \\
\text { (With Controls) }\end{array}$ & $\begin{array}{c}\text { (3) } \\
\text { Interactive Model } \\
\text { (No Controls) } \\
\end{array}$ & $\begin{array}{c}\text { (4) } \\
\text { Interactive Model } \\
\text { (With Controls) }\end{array}$ \\
\hline SOLS Change & $\begin{array}{l}0.187 * * * \\
(0.050)\end{array}$ & $\begin{array}{l}0.178^{* * *} \\
(0.054)\end{array}$ & $\begin{array}{l}0.323^{* * *} \\
(0.080)\end{array}$ & $\begin{array}{l}0.335^{* * *} \\
(0.095)\end{array}$ \\
\hline Other Leader Transition & $\begin{array}{c}0.074 \\
(0.057)\end{array}$ & $\begin{array}{c}0.072 \\
(0.057)\end{array}$ & $\begin{array}{c}0.090 \\
(0.076)\end{array}$ & $\begin{array}{c}0.090 \\
(0.076)\end{array}$ \\
\hline Democracy & $\begin{array}{l}-0.383^{* * *} \\
(0.059)\end{array}$ & $\begin{array}{l}-0.360^{* * * *} \\
(0.062)\end{array}$ & $\begin{array}{l}-0.350^{* * *} \\
(0.062)\end{array}$ & $\begin{array}{l}-0.332 * * * \\
(0.064)\end{array}$ \\
\hline SOLS Change $X$ & & & $-0.256 * * *$ & $-0.271 * *$ \\
\hline Democracy & & & $(0.097)$ & $(0.110)$ \\
\hline Other Leader Transition X & & & -0.041 & -0.043 \\
\hline Democracy & & & $(0.118)$ & $(0.118)$ \\
\hline Regime Transition & & $\begin{array}{c}0.066 \\
(0.114)\end{array}$ & & $\begin{array}{l}-0.022 \\
(0.125)\end{array}$ \\
\hline Cold War End & & $\begin{array}{c}0.058 \\
(0.064)\end{array}$ & & $\begin{array}{c}0.058 \\
(0.064)\end{array}$ \\
\hline US Ally & & $\begin{array}{l}-0.143 \\
(0.125)\end{array}$ & & $\begin{array}{l}-0.149 \\
(0.126)\end{array}$ \\
\hline USSR Ally & & $\begin{array}{c}0.078 \\
(0.210)\end{array}$ & & $\begin{array}{c}0.086 \\
(0.211)\end{array}$ \\
\hline Constant & $\begin{array}{l}-2.536 * * * \\
(0.024)\end{array}$ & $\begin{array}{l}-2.504^{* * *} \\
(0.052)\end{array}$ & $\begin{array}{l}-2.548^{* * *} \\
(0.026)\end{array}$ & $\begin{array}{l}-2.512 * * * \\
(0.053)\end{array}$ \\
\hline Observations & 7,049 & 7,049 & 7,049 & 7,049 \\
\hline Number of Countries & 165 & 165 & 165 & 165 \\
\hline
\end{tabular}

(Notes. Robust standard errors in parentheses; ${ }^{* *} p<0.01,{ }^{* *} p<0.05,{ }^{*} p<0.1$; two-tailed). 
Models $1 \& 2$ both indicate a statistically significant positive effect of SOLS change on UNGA vote change. In line with Hypothesis 1, years in which a new leader with a different societal base of support than her predecessor assumes office experience significantly more UNGA vote change than years in which the same leader remains in power. On the other hand, leader transitions in which a new leader with the same domestic support groups comes to power do not appear to be associated with greater change in UNGA voting than years with no change in leader. While positive, the coefficient for Other Leader Transition is not statistically significant. To compare the effect of SOLS changes and non-SOLS change leader transitions on UNGA voting, we conduct a Wald test. Despite the fact that the coefficient for SOLS Change is larger than that of Other Leader Transition, the two are not statistically different from one another at conventional levels ( $p=.152$ for Model 1 and $p=.189$ for Model 2 ). We thus conclude that the empirical evidence for Hypothesis 1 is mixed. While SOLS changes are more consistently associated with UNGA vote change than other leader transitions, their effect is not necessarily larger in a sample of all cases.

Regarding Hypothesis 2, we find that, as expected, democratic institutions have a constraining effect on a country's foreign policy. The coefficient for Democracy is negative and statistically significant, indicating that there is significantly less year-to-year change in the UNGA voting patterns of continuing democracies than of nondemocracies.

A comparison of Models 1 and 2 shows that our conclusions about Hypotheses 1 and 2 are unaffected by the inclusion of the control variables: Regime Transition, Cold War End, US Ally, and USSR Ally. None of the control variables reach conventional levels of statistical significance, though the coefficients for Regime Transition, Cold War End, and US Ally are in 
the expected direction. ${ }^{19}$ It is noteworthy that the period from 1989-1991, which we would consider a period of major upheaval in the international system, does not appear to be associated with significant change in patterns of UNGA voting. ${ }^{20}$

In order to establish how the effects of both SOLS changes and other leader transitions differ between democracies and nondemocracies, we estimate models that interact SOLS Change and Other Leader Transition with Democracy. ${ }^{21}$ Model 3 includes only the theoretical variables of interest and Model 4 introduces the control variables. In both models, the coefficient for SOLS Change X Democracy is negative and statistically significant, suggesting that the effect of SOLS

${ }^{19}$ Note that since Democracy measures whether the country is democratic in the current year and the previous year, the Regime Transition coefficient in this model should be interpreted in reference to the remaining category of continuing nondemocracies; we find no statistically significant difference between years of regime change and years of continuing nondemocracy, which are also less stable than continuing democracies. In a bivariate model, Regime Transition has a positive and statistically significant effect on UNGA voting change, as we would expect. ${ }^{20}$ However, when we disaggregate the Cold War End variable into dummies for each of the three years, we find that the 1991 indicator is positive and statistically significant. The size of this coefficient is not significantly different from that of SOLS change.

${ }^{21}$ Because, based on our coding rules, SOLS changes are always accompanied by leader transitions, we do not interact SOLS changes with leader transitions and include a three-way interaction with Democracy. Some of the categories of such interaction terms would be empty. All possible combinations of SOLS changes, leader transitions, and democratic institutions are captured by the inclusion of SOLS Change $x$ Democracy and Other Leader Transition $x$ Democracy. 
changes is larger in nondemocracies than in democracies. In fact, while SOLS changes have a significant positive effect in non-democracies $(p<.001$ in Models $3 \& 4)$, they do not have a statistically significant effect in democracies ( $p=.265$ in Model 3; $p=.292$ in Model 4). Compared to years with no leader transition, SOLS change years are more likely to exhibit change in UN voting in nondemocracies, but this is not consistently the case in democracies. This is fully in line with Hypothesis 3. Furthermore, as the negative and statistically significant coefficient for Democracy indicates, democracies tend to exhibit less change in UNGA voting even in years in which there is no leadership change at all (i.e. when Other Leader Transition and SOLS Change are both 0 ).

While we find clear differences regarding the effect of SOLS changes in democracies and nondemocracies, there is no indication that the effect of other leader transitions differs across the two regime types. While negative, the coefficient for Other Leader Transition $X$ Democracy is not statistically significant. Furthermore, the marginal effect of Other Leader Transition is neither significant in nondemocracies ( $p=.236$ for Model 3; $p=.240$ for Model 4) nor in democracies ( $p=.577$ for Model 3; $p=.592$ for Model 4). Whether in democracies or nondemocracies, leader transition years that are not also associated with a change in the source of leader support do not appear to experience greater UNGA vote change than years in which there is no leader transition.

These results mirror the main findings from Models 1 \& 2: SOLS changes consistently have a statistically significant positive effect on UNGA vote change, but other leader transitions do not. However, a difference between Models $1 \& 2$ and Models 3 \& 4 emerges. Wald tests that compare the coefficients of SOLS Change and Other Leader Transition show that there is a statistically significant difference in the size of these coefficients $(p=.043$ for Model 3; $p=.050$ 
for Model 4). ${ }^{22}$ Nondemocracies experience significantly greater changes in UNGA voting patterns when a new leader with a different SOLS comes to power than when a leader that has the same SOLS comes to power or there is no leader change. In democracies, on the other hand, the effect of SOLS changes is no different from the effect of other leader transitions, which in turn is no different from years without a leader transition. Overall then we can conclude that our findings provide support for Hypothesis 3.

In order to probe the robustness of our results, we estimated additional models with different specifications. ${ }^{23}$ First, we conducted analyses in which we contrasted democratic country-years with purely nondemocratic country-years, excluding cases of regime transition. The results are in line with our main findings: SOLS changes have a significant effect on UNGA vote change, especially in non-democracies, while other leader transitions do not; the coefficients for the two types of leader transitions are significantly different ( $p=.059$ in Model 3; $p=.053$ in Model 4). We are thus confident that we are capturing differences between democracies and nondemocracies rather than between democracies and transitional regimes.

Second, we conducted multiple analyses with additional control variables in Models 2 \& 4: absolute value of the percentage change in the country's national capabilities from t-1 to t, absolute value of the percentage change in the country's GDP per capita from t-1 to t, and a dummy variable for Cold War years. We find that year-to-year changes in relative capabilities

${ }^{22}$ Given that these two coefficients capture the effect of these two types of leader transitions when Democracy is 0, we can conclude that there is a statistically significant difference between the effect of SOLS changes and the effect of other leader transitions for nondemocracies.

${ }^{23}$ Further information on the operationalization of new control variables and results of the robustness checks are available in the web appendix. 
have a statistically significant positive effect on UNGA vote change, but year-to-year GDP changes do not. Interestingly and counter to traditional expectations, we also find that the average year-to-year changes in UNGA voting were significantly larger during the Cold War than thereafter. The main results are similar when these control variables are included: especially in non-democracies, SOLS changes have a significant effect on UNGA vote change, but other leader transitions do not; the coefficients for SOLS Change and Other Leader Transition are different at the $90 \%$ confidence level.

Third, to ensure that our SOLS change variable is not simply capturing the effect of coups, revolts, or assassinations, we excluded the entire tenure of leaders who came to power through “irregular” means, as coded by Archigos (Goemans et al. 2009). When the control variables are included, we find that SOLS change does not have a statistically significant effect on UNGA vote change in the full sample (Model 2), but is statistically significant for nondemocracies (Model 4), as predicted by Hypothesis 3. Regarding Model 4, we also find that, as before, non-SOLS change leader transitions have no effect on UNGA vote change and that the coefficient associated with Other Leader Transitions is smaller than that of SOLS change, but the difference is not statistically significant at conventional levels $(p=.174)$. Dropping all leaders who entered office through irregular means constitutes a hard test for the effect of SOLS changes, given that, in nondemocracies especially, the relationship between irregular leader transitions and SOLS changes may be that the latter drive the former rather than the other way around. Also, this entails dropping 32 percent of observations in the sample. Even in this hard test, however, we uncover basic patterns that are in line with our hypotheses: SOLS changes have a systematic and discernible impact on UNGA vote change in nondemocracies, while other 
leader transitions that are not associated with a SOLS change have no clear effect on UNGA vote change. $^{24}$

Overall, we conclude that our hypotheses are largely supported. The support for H1 is mixed. SOLS changes have a statistically significant positive impact on change in UNGA voting patterns, while non-SOLS change leader transitions do not. Yet, the difference between SOLS change leader transitions and other leader transitions is not statistically significant in our full sample. In support of $\mathrm{H} 3$, however, we find that the effect of SOLS changes on UN voting is particularly pronounced for nondemocracies, and in the case of nondemocracies, leader transitions accompanied by SOLS changes result in greater change in UNGA voting than years without leader transitions or other leader transition years. We also find support for $\mathrm{H} 2$. Democracies exhibit more consistency in their UNGA voting than nondemocracies do.

\section{Conclusion}

IR scholarship has traditionally been more successful at explaining foreign policy continuity rather than change. Part of the problem lies in the excessive focus on the structure of the international system and basic state characteristics like power and geographic position. Given the relatively immutable nature of these factors, they explain continuity well but fall short if the goal is to predict change. The basic premise of this paper is that if we want to understand foreign policy change we need to consider domestic political processes. Domestic changes that bring to

\footnotetext{
${ }^{24}$ To account for the potential importance of individual states and years to our results, we also ran each of our models dropping each state and each year from the sample. The results were substantively similar.
} 
power new leaders with different societal support groups can be a powerful source of change. If leaders represent different interests and preferences than their predecessors, they may opt to pursue a distinct foreign policy course. This effect is mediated, however, by domestic political institutions. Domestic changes should exert a stronger effect in nondemocracies than in democracies.

Our empirical focus in this study lies in explaining changes in countries’ UN voting patterns. Voting in the UNGA is not only a frequently used measure of foreign policy preferences, but it is also particularly useful for gauging the effect of domestic political changes on foreign policy positions. The opportunity to vote in the UNGA occurs under virtually every leader, and voting is a monadic activity. Leaders are constrained by international law when it comes to changing policies enshrined in treaties, but there are no such constraints on UN voting. This suggests that new leaders have more leeway in changing foreign policy positions in the UN than elsewhere. It also means that any stability that we observe is likely to have been induced by domestic institutions rather than international ones.

Using new data that allows us to measure change in UNGA voting and new data on changes in leaders' sources of domestic support, we find that SOLS changes are consistently a significant predictor of foreign policy change in nondemocracies but not in democracies. We also find that, in nondemocracies, the effect of SOLS changes on UNGA voting is larger than the effect of other leader transitions. Finally, we observe more consistency in UNGA voting in democracies than nondemocracies, both in years with no leader transitions and in SOLS change years.

Our study supports a perspective that views foreign policymaking as intertwined with the domestic policymaking process, whereby groups compete to advance their interests and 
implement their preferred policies within given institutional rules. The fact that foreign policy generally involves strategic interaction with other states does affect both domestic competition over foreign policy and ultimate policy choices, but politics does not entirely "stop at the water's edge.” This suggests that policymakers hoping to predict foreign policy change should pay particular attention to the dynamics of domestic political competition and leadership selection, particularly in nondemocracies. 


\section{References}

Achen, Christopher H. (2005) Let’s Put Garbage-Can Regressions and Garbage-Can Probits Where They Belong. Conflict Management and Peace Science 22 (4): 327-339.

Bailey, Michael A. (2007) Comparable Preference Estimates across Time and Institutions for the Court, Congress, and Presidency. American Journal of Political Science 51 (3): 433-448.

Bailey, Michael, Anton Strezhnev, And EriK Voeten. (2013) Estimating Dynamic State Preferences from United National Voting Data (SSRN Scholarly Paper No. ID 2330913). Rochester, NY: Social Science Research Network. Retrieved from http://papers.ssrn.com/abstract=2330913

Bueno de Mesquita, Bruce, Alastair Smith, Randolph M. Siverson, and James D. Morrow. (2003) The Logic of Political Survival. Cambridge: The MIT Press.

Carter, David B. And Randall W. Stone. forthcoming. Democracy and Multilateralism: The Case of Vote Buying in the UN General Assembly. International Organization.

Cheibub, Jose Antonio, Jennifer Gandhi, And James Vreeland. (2010) Democracy and Dictatorship Revisited. Public Choice 144 (1-2): 67-101.

Clarke, KeVin A. (2005) The Phantom Menace: Omitted Variable Bias in Econometric Research. Conflict Management and Peace Science 22 (4): 341-352.

Cooley, AleXander. (2012) Base Politics: Democratic Change and the US Military Overseas. Ithaca: Cornell University Press.

Davis, DAVID R. AND Will H. MoORE. (1997) Ethnicity Matters: Transnational Ethnic Alliances and Foreign Policy Behavior. International Studies Quarterly 41 (1): 171-184. 
Dreher, Axel and Nathan Jensen. (2013) Country or Leader? Political Change and UN General Assembly Voting. European Journal of Political Economy 29:183-196.

Dreher, Axel, Peter Nunnenkamp, and Rainer Thiele. (2008) Does US Aid Buy UN General Assembly Votes? A Disaggregated Analysis. Public Choice 136 (1): 139-164. Dreher, Axel And Jan-EgBert Sturm. (2012) Do the IMF and the World Bank Influence Voting in the UN General Assembly? Public Choice 151 (1): 363-397.

Fordham, Benjamin O. (1998) Building the Cold War Consensus: The Political Economy of US National Security Policy, 1949-1951. Ann Arbor: University of Michigan Press. GARTZKE, ERIK. (1998) Kant We All Just Get Along?: Opportunity, Willingness, and the Origins of the Democratic Peace. American Journal of Political Science 42 (1): 1-27.

Gaubatz, KuRT TAYlor. (1996) Democratic States and Commitment in International Relations. International Organization 50 (1): 109-139.

GedDEs, BARBARA. (1999) What Do We Know About Democratization after 20 Years? Annual Review of Political Science 2: 115-144.

Geddes, Barbara, Joseph Wright and ERICA Frantz. (2012) Authoritarian Regimes: A New Data Set. Manuscript. Available at http://dictators.la.psu.edu/ (Accessed May 10, 2012).

GIBLER, Douglas M. (2009) International Military Alliances, 1648-2008. Washington, DC: Congressional Quarterly Press.

Goemans, HenK E., Kristian Skrede Gleditsch, and Giacomo ChiozZa. (2009) Introducing Archigos: A Data Set of Political Leaders. Journal of Peace Research 46 (2): 269-283. HAAS, MARK L. (2005) The Ideological Origins of Great Power Politics, 1789-1989. Ithaca: Cornell University Press. 
Hagan, Joe D. (1989) Domestic Political Regime Change and Third World Voting Realignments in the United Nations, 1946-1984. International Organization 43 (3): 505541.

LaI, Brian AND Daniel S. Morey. (2006) Impact of Regime Type on the Influence of US Foreign Aid. Foreign Policy Analysis 2 (4): 385-404.

Leeds, Brett Ashley and Michaela Mattes. (2007) Alliance Politics During the Cold War: Aberration, New World Order, or Continuation of History? Conflict Management and Peace Science 24 (3): 183-199.

Leeds, Brett Ashley, Michaela Mattes, and Jeremy S. Vogel. (2009) Interests, Institutions, and the Reliability of International Commitments. American Journal of Political Science 53 (2): 461-476.

Lipson, Charles. (2003) Reliable Partners. Princeton: Princeton University Press.

Marshall, Monty G., Keith Jaggers, and Ted Robert Gurr. (2010) Polity IV Project: Dataset Users’ Manual. College Park: University of Maryland. Available at http://www.systemicpeace.org/inscr/p4manualv2010.pdf (Accessed April 20, 2012).

Martin, Lisa L.(2000) Democratic Commitments. Princeton: Princeton University Press. McGillivray, Fiona and Alistair Smith. (2008) Punishing the Prince: A Theory of Interstate Relations, Institutions, and Leader Change. Princeton: Princeton University Press.

Milner, Helen V. (1999) The Political Economy of International Trade. Annual Review of Political Science 2: 91-114.

Moon, BRuCE E. (1985) Consensus or Compliance? Foreign Policy Change and External Dependence. International Organization 39 (2): 297-329. 
MorAvsciK, ANDREW. (1997) Taking Preferences Seriously: A Liberal Theory of International Politics. International Organization 51 (4): 513-553.

NARIZNY, KEVIN. (2003) Both Guns and Butter, or Neither: Class Interests in the Political Economy of Rearmament. American Political Science Review 97 (2): 203-220.

NARIZnY, KEVIN. (2007) The Political Economy of Grand Strategy. Ithaca: Cornell University Press.

OlcotT, Martha BriLl. (2005) Central Asia’s Second Chance. Washington, D.C.: Carnegie Endowment.

PotrafKe, NiKLAS. (2009) Does Government Ideology Influence Political Alignment with the US? An Empirical Analysis of Voting in the UN General Assembly. The Review of International Organizations 4 (3): 245-268.

Rathbun, Brian C. (2004) Partisan Interventions: European Party Politics and Peace Enforcement in the Balkans. Ithaca: Cornell University Press.

RAY, JAMES LEE. (2003) Explaining Interstate Conflict and War: What Should Be Controlled For? Conflict Management and Peace Science 20 (1): 1-31.

ShoemaKer, M. Wesley. (2013) Russia and the Commonwealth of Independent States 2013. Lanham, MD: Rowman and Littlefield.

Solingen, Etel. (2007) Nuclear Logics: Contrasting Paths in East Asia and the Middle East. Princeton: Princeton University Press.

SNYDER, JACK. (1991) Myths of Empire: Domestic Politics and International Ambition. Ithaca: Cornell University Press.

Strezhnev, Anton And ErIK Voeten. (2013) United Nations General Assembly Voting Data. Available at http://hdl.handle.net/1902.1/12379 (Accessed March 9, 2014). 
Trubowitz, Peter. (1998) Defining the National Interest: Conflict and Change in American Foreign Policy. Chicago: The University of Chicago Press.

VENGROFF, Richard. (1976) Instability and Foreign Policy Behavior: Black Africa in the UN. American Journal of Political Science 20 (3): 425-438.

VOETEN, ERIK. (2000) Clashes in the Assembly. International Organization 54 (2): 185-215.

VOETEN, ERIK. (2001) Domestic Institutional Change and the External Orientation of States. Georgetown University: Manuscript.

VOETEN, ERIK. (2004) Resisting the Lonely Superpower: Responses of States in the United Nations to US Dominance. Journal of Politics 66 (3): 729-754.

VOETEN, ERIK. (2013) “Data and Analyses of Voting in the UN General Assembly.” in Routledge Handbook of International Organization, ed. Bob Reinalda. Routledge: London.

WANG, T.Y. (1999) US Foreign Aid and UN Voting: An Analysis of Important Issues. International Studies Quarterly 43 (1): 199-210. 